\title{
Adaptability of Indocalamus decorus to climate change based on physio- logical and biochemical responses to elevated carbon dioxide and ozone
}

\author{
Ziwu Guo ${ }^{(1)}$, Minghao Zhuang ${ }^{(2)}$, \\ Yingchun Li ${ }^{(1)}$, Shuanglin Chen ${ }^{(1)}$, \\ Qingping Yang ${ }^{(1)}$
}

Carbon dioxide $\left(\mathrm{CO}_{2}\right)$ and ozone $\left(\mathrm{O}_{3}\right)$ are important greenhouse gases that contribute to global climate change. The effects of elevated $\mathrm{CO}_{2}$ and/or $\mathrm{O}_{3}$ on plants remain unclear. Plant responses to mixtures of the two gases at high concentrations are likely to be complex. Previous studies have shown that the ability to tolerate elevated levels of the two gases varies among plant species; physiological adaptability in the face of changing atmospheric composition also differs among taxa. However, the effects of mixtures of the two greenhouse gases on the growth and physiology of bamboo are largely unexplored, even though bamboos are important vegetation elements throughout tropical and subtropical regions of the planet. In this study, we used open-topped chambers (OTC) to double the concentrations of atmospheric $\mathrm{CO}_{2}$ and $\mathrm{O}_{3}$, and examined changes in membrane lipid peroxidation, photosynthetic physiology, and antioxidase activities in Indocalamus decorus leaves. After 103 days of treatment, elevated $\mathrm{O}_{3}$ depressed net photosynthetic rate $(\mathrm{Pn})$ without changing stomatal function, but caused no significant oxidative damage in the leaves. High levels of antioxidase activities were maintained in the leaves, indicating that this species had a strong tolerance to elevated $\mathrm{O}_{3}$. Decreases in reactive oxygen content and antioxidase activity in the leaves highlighted the significant positive effects of elevated $\mathrm{CO}_{2}$ on photosynthesis in $I$. decorus. When a mixture of both gases was supplied at high concentrations, we detected no oxidative damage, although photosynthetic capacity was reduced. Negative effects of $\mathrm{O}_{3}$ were very marked during the early part of the treatment period, but the effects of $\mathrm{CO}_{2}$ were positive. $\mathrm{CO}_{2}$ mitigated the oxidative damage caused by $\mathrm{O}_{3}$ and promoted the growth of $I$. decorus. Thus, I. decorus tolerated the two greenhouse gases, and was able to adapt to elevated $\mathrm{CO}_{2}$ and $\mathrm{O}_{3}$ levels. These findings contribute to the current knowledge base on the response of bamboo to global climate change.

Keywords: Antioxidant Enzyme, Carbon Dioxide, Indocalamus decorus, Membrane Lipid Peroxidation, Ozone, Photosynthetic Physiology

sions of nitrogen oxides (NOx) and oxygen-containing volatile organic compounds (VOCs), have increased atmospheric $\mathrm{CO}_{2}$ and $\mathrm{O}_{3}$ concentrations to levels that are significantly higher than those prior to the industrial revolution. The rate of increase has been relatively stable over time. By 2050, the atmospheric $\mathrm{CO}_{2}$ concentration is expected to reach concentrations that will be double those of preindustrial levels; $\mathrm{O}_{3}$ is increasing by up to $2.5 \%$ annually (IPCC
(1) Research Institute of Subtropical Forestry, Chinese Academy of Forestry, Hangzhou Zhejiang, 311400 (P.R. China); (2) College of Environmental Sciences and Engineering, Peking University, Beijing 100871 (P.R. China)

@ Shuanglin Chen (hunt-panther@163.com)

Received: Jan 23, 2015 - Accepted: Aug 18, 2015

Citation: Guo Z, Zhuang M, Li Y, Chen S, Yang Q (2015). Adaptability of Indocalamus decorus to climate change based on physiological and biochemical responses to elevated carbon dioxide and ozone. iForest 9: 311-317. - doi: 10.3832/ifor1571-008 [online 2015-10-22]

Communicated by: Silvano Fares
2007). Significant increases in $\mathrm{CO}_{2}$ and $\mathrm{O}_{3}$ concentrations will lead to increased radiation levels and contribute to global warming, and they will also directly affect the microscopic structures, physiological and biochemical functions, and the growth and development of plants and ecosystems. Thus, the impacts of increased surface layer $\mathrm{CO}_{2}$ and $\mathrm{O}_{3}$ concentrations on plants have been a focus of attention worldwide (Gaucher et al. 2006, Noormets et al. 2010). $\mathrm{O}_{3}$ is a strong oxidant that enters plant tissues via the stomatal apertures. This gas may cause visible leaf injuries (Guidi et al. 2000), inhibit plant growth, and reduce plant height, leaf area (Bai et al. 2005) and biomass (Pleijel et al. 2006). $\mathrm{O}_{3}$ also increases leaf malonyldialdehyde (MDA) and reactive oxygen species contents, membrane permeability, and membrane lipid peroxidation (Tausz et al. 2007). It reduces chlorophyll content, changes chloroplast structure, reduces the number and activity of photosynthetic enzymes and the photosynthetic rate, and changes the distribution of photosynthetic products (Meyer et al. 2000, Noormets et al. 2001). 
$\mathrm{CO}_{2}$ is a photosynthetic substrate; changes in its atmospheric concentration are likely to affect physiological and biochemical reactions in plants. Many previous studies have demonstrated that elevated $\mathrm{CO}_{2}$ levels may promote plant growth (Noormets et al. 2001, Nowak et al. 2004) and improve plant photosynthesis performance (Donnelly et al. 2001, Wang et al. 2007). Plants subjected to high $\mathrm{CO}_{2}$ levels also reduce their rates of reactive oxygen species generation, thereby balancing metabolic function and maintaining cell stability (Vurro et al. 2009). Thus, elevated $\mathrm{O}_{3}$ levels may damage plants, but elevated $\mathrm{CO}_{2}$ concentrations may promote photosynthesis and accelerate metabolism. Is the damage caused by increases in $\mathrm{O}_{3}$ offset by the benefits conferred by increased $\mathrm{CO}_{2}$ levels? The results of investigations into plant responses to combinations of elevated $\mathrm{CO}_{2}$ and $\mathrm{O}_{3}$ are inconsistent. Some studies indicate that elevated $\mathrm{CO}_{2}$ may reduce stomatal conductance, thereby limiting the volume of $\mathrm{O}_{3}$ entering leaves, or raise antioxidant enzyme activity to alleviate the damage inflicted by $\mathrm{O}_{3}$ (Gaucher et al. 2003, Darbah et al. 2008). However, other studies indicate that elevated $\mathrm{CO}_{2}$ does not mitigate the negative effects of $\mathrm{O}_{3}$ on plants (Paoletti et al. 2007); long-term elevation of $\mathrm{CO}_{2}$ may even exacerbate the damage caused by $\mathrm{O}_{3}$ (Wustman et al. 2001).

Bamboo is an unusual evergreen plant. It grows rapidly, can be sustainably managed after reafforestation, and provides a variety of useful products and services for human use. It has important roles in regional water and soil conservation, carbon fixation, oxygen emission, and climate regulation, making it an important element of terrestrial ecosystems. Indocalamus decorus, a member of the subfamily Bambusoideae (family Poaceae), has sympodial rhizomes and large green leaves. The species is very adaptable across a wide range of environmental conditions, including low temperatures, drought and barren soil. Accordingly, it is widely used in soil stabilization and landscaping (hedging, stratified planting, etc.). In the present study, we aimed to identify the mechanisms underlying the physiological and biochemical responses of bamboo plants to elevated atmospheric $\mathrm{CO}_{2}$ and $\mathrm{O}_{3}$, and provide reference data for the adaptive management of bamboo plants during changes in global climate. Thus, we investigated the shifts in membrane lipid peroxidation, photosynthetic physiology, and antioxidant enzymes in $l$. decorus leaves exposed to doubled $\mathrm{CO}_{2}$ and $\mathrm{O}_{3}$ concentrations in open-topped chambers (OTCs).

\section{Materials and methods}

\section{Experimental site}

The experimental site was located in the Hangzhou Lin'an Taihuyuan Ornamental Bamboo Planting Garden, Taihuyuan Township, Lin'an City, Zhejiang Province, China $\left(29^{\circ} 56^{\prime}-30^{\circ} 23^{\prime} \mathrm{N}, 118^{\circ} 51^{\prime}-119^{\circ} 72^{\prime} \mathrm{E}\right)$. The region has a typical central Chinese subtropical climate with an annual precipitation of 1250-1600 mm. The average annual temperature was $15.4^{\circ} \mathrm{C}$; the maximum and minimum temperatures were $40.2{ }^{\circ} \mathrm{C}$ and $-13.3{ }^{\circ} \mathrm{C}$, respectively. The average annual frost-free period was 233 days (d).

\section{Experimental materials}

I. decorus specimens were planted with soil-free roots into 120 pots during March 2011. Each black plastic pot held $2051.5 \mathrm{~cm}^{3}$ of soil. The potting medium was a uniform mixture of red soil and silver sand (3:1 $\mathrm{vol} / \mathrm{vol}$ ) with a $\mathrm{pH}$ value of 5.8 , a hydrolyzable nitrogen level of $198.47 \mathrm{mg} \mathrm{kg}^{-1}$, an available phosphorus level of $67.25 \mathrm{mg} \mathrm{kg}^{-1}$, and an available potassium level of 74.16 mg kg-1. We transplanted 15 annual specimens with normal rhizomes in clumps and dark green leaves into each pot. The mean diameter and height of the plants were $4.54 \pm 0.08 \mathrm{~mm}$ and $37.28 \pm 0.15 \mathrm{~cm}$, respectively. We manually watered at regular intervals, and managed bamboo shoots and weeds regularly. The experimental treatments with elevated $\mathrm{CO}_{2}$ and $\mathrm{O}_{3}$ began in July 2011.

\section{Experimental design and methods}

OTCs were constructed from stainless steel tubes and colorless clear glass. The eight-prism chamber had an octagonal base, a 4-m high aboveground section and a o.8-m belowground section; the upper walls leaned inward at an angle of $45^{\circ}$. The aboveground section was wrapped with impermeable clear glass, leaving the top totally open. The bottom was an octagon with sides of $1.5 \mathrm{~m}$ and a height of $4 \mathrm{~m}$. Carbon dioxide and ozone were obtained from steel cylinders of pure $\mathrm{CO}_{2}$ and from a CFG-2O $\mathrm{O}_{3}$ generator (Sankang Environmental Technology Co., Ltd., Jinan, China), respectively. Ambient atmospheric air was filtered through activated carbon. The supplementary gases were supplied to the chambers through pressure-relief valves. The volume of additional air added was calculated from the air chamber volume and the flow velocity through an axial flow ventilator; adjustments were made with a flow meter. Supplementary gases were supplied to the OTCs by $750 \mathrm{~W}$ ventilation pumps.

We applied four treatments: (i) controls (ambient air, with an $\mathrm{O}_{3}$ concentration of $40 \pm 5 \mathrm{nmol} \mathrm{ml}^{-1}$, and a $\mathrm{CO}_{2}$ concentration of $\left.360 \pm 20 \mu \mathrm{mol} \mathrm{ml}^{-1}\right)$; (ii) EO treatment $\left(\mathrm{O}_{3}\right.$ concentration of $100 \pm 10 \mathrm{nmol} \mathrm{ml}^{-1}, \mathrm{CO}_{2}$ concentration of $360 \pm 20 \mu \mathrm{mol} \mathrm{ml}^{-1}$ ); (iii) EC treatment $\left(\mathrm{O}_{3}\right.$ concentration of $40 \pm 5$ nmol ml${ }^{-1}, \mathrm{CO}_{2}$ concentration of $700 \pm 35$ $\left.\mu \mathrm{mol} \mathrm{ml} \mathrm{l}^{-1}\right)$; and (iv) ECEO treatment $\left(\mathrm{O}_{3}\right.$ concentration of $100 \pm 10 \mathrm{nmol} \mathrm{ml}^{-1}, \mathrm{CO}_{2}$ concentration of $\left.700 \pm 35 \mu \mathrm{mol} \mathrm{ml}{ }^{-1}\right)$. Each treatment was replicated threefold. We placed ten pots containing experimental $I$. decorus seedlings at a similar growth stage in evenly spaced positions within each air chamber. The $\mathrm{O}_{3}$ and $\mathrm{CO}_{2}$ concentrations in the OTCs were monitored using a Model 205 double beam UV-O 3 analyzer (Kangzhuo Automation Systems Engineering Service Co., Ltd., Shanghai, China) and a $\mathrm{CO}_{2}$ infrared sensor (Zhuoxing Environmental Instrument Co., Ltd., Shanghai, China), respectively. Concentrations were measured in the upper, middle, and lower regions of the air chambers at $3 \mathrm{~d}$ intervals.

The experiment began on 10 July 2011 and ended on 30 October 2011. We provided $\mathrm{O}_{3}$ on each experimental day from 07:00 to 17:00. $\mathrm{CO}_{2}$ was provided continually.

\section{Determination of photosynthetic gas} exchange parameters

During a one hour period (09:00-10:00) on two sunny days in the course of the treatment process (days 55 and 103), we selected three complete mature leaves of I. decorus in each OTC and measured their net photosynthetic rate $(\mathrm{Pn})$, transpiration rate (E), stomatal conductance (Gs), and intercellular $\mathrm{CO}_{2}$ concentration (Ci) using a LiCor-6400 portable photosynthesis system analyzer (Licor, Lincoln, NE, USA) equipped with a standard assimilation chamber $(2 \times 3 \mathrm{~cm})$ under standardized conditions (photon flux: $900 \mu \mathrm{mol} \mathrm{m} \mathrm{m}^{-2} \mathrm{~s}^{-1}$; relative humidity: $75 \%$; temperature: $29^{\circ} \mathrm{C}$ ).

\section{Determination of physiological} indicators

In the mornings (10:00-10:30) of treatment days 55 and 103, we randomly selected a mixed sample of 10-12 mature leaves of $I$. decorus from each air chamber (following completion of photosynthetic gas exchange parameter measurements) and determined their main physiological and biochemical indexes.

\section{Chlorophyll content and electrolyte leakage rate}

Chlorophyll content was estimated following the method described by Zhang \& Chen (1994), with slight modifications. We extracted $50 \mathrm{mg}$ samples in a mixture of $2.5 \mathrm{ml}$ acetone and $2.5 \mathrm{ml}$ ethanol for $24 \mathrm{~h}$ in darkness at room temperature. After extraction, we measured absorbances spectrophotometrically at 663 and $645 \mathrm{~nm}$ to calculate the contents of chlorophyll $a$ and $b$, and total chlorophyll.

Electrolyte leakage rate was estimated by measuring electric conductance. Twenty leaf discs with a diameter of $8 \mathrm{~mm}$ were rinsed with distilled water, submerged in $20 \mathrm{ml}$ distilled water, vacuum infiltrated for $20 \mathrm{~min}$ and then shaken for $2 \mathrm{~h}$ to measure the initial electric conductance (S1). Samples were digested in water at $100{ }^{\circ} \mathrm{C}$ for 20 min to determine the final electric conductance (S2). The electrolyte leakage was calculated as: $\mathrm{EL}(\%)=\left(\mathrm{S}_{1} / \mathrm{S}_{2}\right) \times 100$.

\section{Superoxide anion radical $\left(\mathrm{O}_{2}^{\circ}\right)$ and MDA contents}

$\mathrm{O}_{2} \cdot$ - content was determined by the hydroxylamine oxidation method of Ke et al. (2002), with slight modification. Fresh lea- 
ves ( $0.5 \mathrm{~g})$ were ground in liquid nitrogen with $5 \mathrm{ml}$ of $50 \mathrm{mM}(\mathrm{pH} 7.8)$ phosphate buffer using a mortar and pestle. The homogenate was filtered through a $45 \mu \mathrm{m}$ nylon mesh and centrifuged at $10500 \times \mathrm{g}$ for $20 \mathrm{~min}$ at $4{ }^{\circ} \mathrm{C}$. We added $1 \mathrm{ml}$ of hydroxylammonium chloride ( $1 \mathrm{mM})$ to $0.5 \mathrm{ml}$ of the supernatant and incubated the combination for $10 \mathrm{~min}$ at $25^{\circ} \mathrm{C}$. We subsequently added $1 \mathrm{ml} \mathrm{4-aminobenzenesulfonic} \mathrm{acid}$ (17 $\mathrm{mM})$ and $1 \mathrm{ml} \alpha$-aphthylamine $(7 \mathrm{mM})$ and held the mixture for $20 \mathrm{~min}$ at $25^{\circ} \mathrm{C}$ to develop the color. Specific absorption was measured at $530 \mathrm{~nm}$. Sodium nitrite was used as the standard solution to calculate the content of $\mathrm{O}_{2} \therefore$.

The MDA content was determined by the thiobarbituric acid (TBA) method. We transferred $1.5 \mathrm{ml}$ of the centrifugation supernatant to a stoppered test tube containing $2.5 \mathrm{ml}$ of $0.5 \%$ TBA solution. The mixture was incubated in a boiling water bath for $20 \mathrm{~min}$, cooled and centrifuged. We measured the absorbances of the supernatant at $532 \mathrm{~nm}, 600 \mathrm{~nm}$ and $450 \mathrm{~nm}$, and calculated MDA concentration ( $\mu \mathrm{mol} \mathrm{L}^{-1}$ ) as: $\mathrm{MDA}=6.45 \times\left(\mathrm{OD}_{532}-\mathrm{OD}_{600}\right)-0.560 \mathrm{D}_{450}$ (Chen \& Wang 2006).

\section{Enzyme extraction and assay}

Fresh leaves $(0.5 \mathrm{~g})$ were ground in liquid nitrogen using a mortar and pestle; ground samples were individually homogenized in an ice bath in $10 \mathrm{ml}$ of $50 \mathrm{mM}$ phosphate buffer ( $\mathrm{pH}$ 7.8). The homogenate was centrifuged at $10500 \times \mathrm{g}$ for $15 \mathrm{~min}$ at $4{ }^{\circ} \mathrm{C}$. The supernatant was used for the following enzyme assays.

Superoxide dismutase (SOD; EC 1.15.1.1) activity was assayed by monitoring the inhibition of the photochemical reduction of nitroblue tetrazolium (NBT). The $3 \mathrm{ml}$ reaction mixture contained $50 \mathrm{mM}$ phosphate buffer ( $\mathrm{pH} 7.8), 13 \mathrm{mM}$ methionine, $75 \mu \mathrm{M}$ NBT, $2 \mu \mathrm{M}$ riboflavin, $0.1 \mathrm{mM}$ EDTA, and $0.05 \mathrm{ml}$ of enzyme extract. Reaction mixtures were illuminated for $20 \mathrm{~min}$ at a photon flux of $72 \mu \mathrm{mol} \mathrm{m} \mathrm{m}^{-2} \mathrm{~s}^{-1}$. One unit of SOD activity was defined as the amount of enzyme required to cause a $50 \%$ inhibition of NBT (monitored at $560 \mathrm{~nm}$ - Chen \& Wang 2006).

Peroxidase (POD; EC 1.11.1.7) activity was measured using the guaiacol oxidation method. The assay mixture contained $1 \mathrm{ml}$ of $0.3 \% \mathrm{H}_{2} \mathrm{O}_{2}, 0.95 \mathrm{ml}$ of $0.2 \%$ guaiacol and 1 $\mathrm{ml}$ of $50 \mathrm{mM}$ phosphate buffer ( $\mathrm{pH} 7.0$ ). We added $0.05 \mathrm{ml}$ of enzyme solution to the reaction mixture to make up a total volume of $3.0 \mathrm{ml}$. To calculate POD activity, we started recording changes in the absorbance of guaiacol (at $470 \mathrm{~nm}$ ) $30 \mathrm{~s}$ after the reaction mixture had been made up, and finished recordings 3.0 min later.

Catalase (CAT; EC 1.11.1.6) activity was determined by directly measuring the decomposition of $\mathrm{H}_{2} \mathrm{O}_{2}$ at $240 \mathrm{~nm}$. The reaction mixture contained $1.0 \mathrm{ml}$ of $0.3 \% \mathrm{H}_{2} \mathrm{O}_{2}$, $1.9 \mathrm{ml}$ of $\mathrm{H}_{2} \mathrm{O}$, and $0.1 \mathrm{ml}$ of enzyme solution. We mixed $0.1 \mathrm{ml}$ of enzyme solution with $2.9 \mathrm{ml}$ of reaction mixture, then added $1.0 \mathrm{ml}$ of $0.3 \% \mathrm{H}_{2} \mathrm{O}_{2}$ to begin the reaction. We recorded absorbances at $240 \mathrm{~nm}$ at 30 $s$ intervals. CAT activity was followed by the decrease in absorbance in the period 0.5-3.0 min after the reaction had been initiated. A decrease of OD by 0.01 per minute was defined as an activity unit (Chen \& Wang 2006).

Ascorbate peroxidase (APX; EC 1.11.1.11) activity was determined by following the decrease in absorbance at $290 \mathrm{~nm}$ (extinction coefficient $2.8 \mathrm{mM}^{-1} \mathrm{~cm}^{-1}$ ) in $3.0 \mathrm{ml}$ of a reaction mixture containing $2.4 \mathrm{ml}$ of 0.5 $\mathrm{mM}$ ascorbate, $0.3 \mathrm{ml}$ of $2 \mathrm{mM} \mathrm{H}_{2} \mathrm{O}_{2}$, and $0.3 \mathrm{ml}$ of enzyme extract (Knorzer et al. 1996).

\section{Statistical analysis}

Microsoft Excel ${ }^{\circledast}$ ver. 2007 was used for data sorting and constructing graphical plots. We used the SPSS ${ }^{\circledast}$ ver. 16.0 statistical software (SPSS Inc., Chicago, IL, USA) to perform one-way analyses of variance
(ANOVA); the least significant difference (LSD) multiple comparisons test was used for pairwise comparisons $(p<0.05)$. All values presented are means \pm SD.

\section{Results}

Effects of elevated $\mathrm{CO}_{2}$ and $\mathrm{O}_{3}$ on contents of $\mathrm{O}_{2} \cdot$ and MDA, and electrolyte leakage rates

By day 55 of the experimental period, the contents of $\mathrm{O}_{2} \cdot-$ and MDA, and the electrolyte leakage rate of leaves in the EO treatment had decreased slightly in comparison with controls. In contrast, the contents of $\mathrm{O}_{2} \cdot$ and MDA in the EC treatment had decreased markedly ( $p<0.05$ - Fig. 1); the electrolyte leakage rate had decreased slightly in comparison with the controls. By day 103 , the $\mathrm{O}_{2}{ }^{-}$content in the $\mathrm{EO}$ treatment had increased slightly, but the MDA content and electrolyte leakage rate had decreased slightly. Measured parameters in the EC treatment had decreased significantly $(p<0.05)$ compared with the controls. By days 55 and 103 of EOEC treatment, the contents of $\mathrm{O}_{2} \cdot{ }^{-}$and MDA, and the electrolyte leakage rate had changed only slightly in comparison with leaves in the control and EO treatment. However, the contents of $\mathrm{O}_{2}^{-}$and MDA in the EOEC treatment were significantly higher than those in the EC treatment $(p<0.05) . \mathrm{O}_{2}{ }^{-}$ contents after 103 days of exposure to all treatments were significantly higher than those measured on day 55 , but MDA contents on day 55 exceeded those on day 103. Electrolyte leakage rates were not significantly different $(p>0.05)$ between days 55 and 103 across all treatments.

\section{Effects of elevated $\mathrm{CO}_{2}$ and $\mathrm{O}_{3}$ on leaf} photosynthetic physiology

Compared with the controls, Pn, Gs and Tr values of $I$. decorus leaves after 55 and 103 days of EO treatment had decreased significantly $(p<0.05)$, but Ci had increased
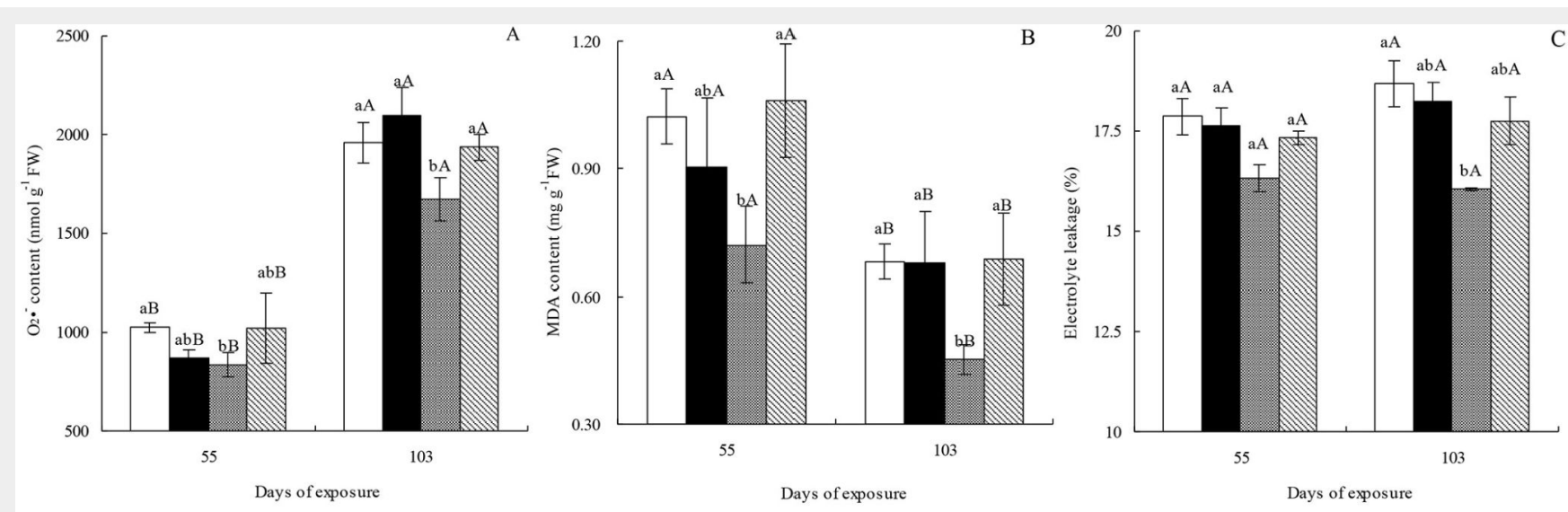

$\square$ Contral $\quad \mathrm{EO} \quad \mathrm{ECC} \mathbb{\mathrm { EOEC }}$

Fig. 1 - Effects of elevated ozone and/or elevated carbon dioxide on (A) superoxide anion radical $\left(\mathrm{O}_{2}{ }^{-}\right)$content, (B) malonyldialdehyde (MDA) content, and (C) electrolyte leakage in the leaves of Indocalamus decorus. Values are means \pm standard deviation of the three independent open-topped chambers (OTCs). Different upper case letters indicate significant differences between days of exposure $(p<0.05)$; different lowercase letters indicate significant differences among treatments $(p<0.05)$. 

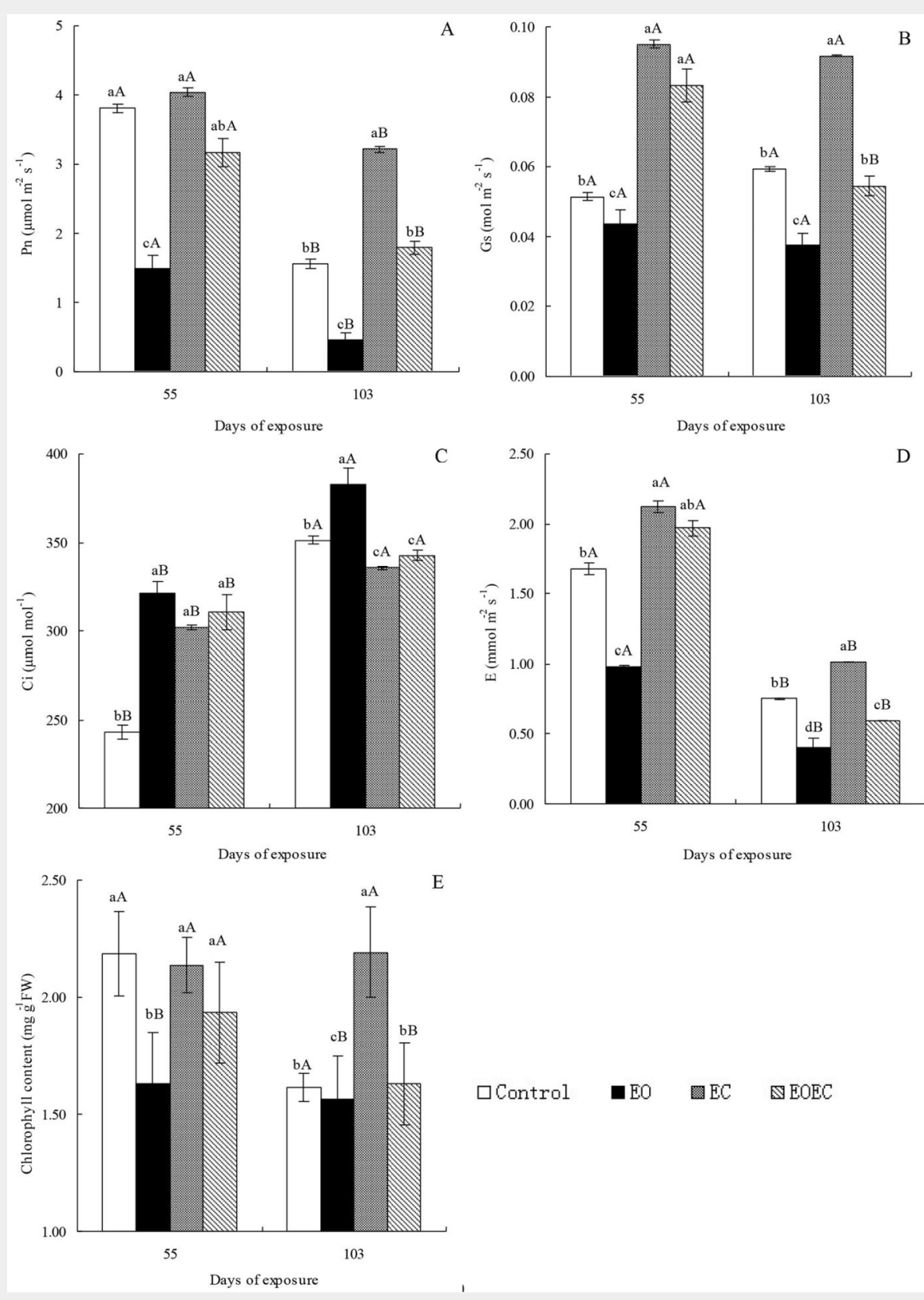

\section{$\square$ Control $\quad \mathrm{EO} \quad \mathrm{EC} \quad \mathrm{E} \mathrm{EOEC}$}

B Fig. 2 - Effects of elevated ozone and/or elevated carbon dioxide on $(A)$ photosynthetic rate $(\mathrm{Pn}),(\mathrm{B})$ stomatal conductance (Gs), (C) intercellular $\mathrm{CO}_{2}$ concentration (Ci), (D) transpiration rate (E), and (E) chlorophyll content in the leaves of Indocalamus decorus. Values are means \pm standard deviation of the three independent open-topped chambers (OTCs). Different upper case letters indicate significant differences between days of exposure $(p<0.05)$; different lowercase letters indicate significant differences among treatments $(p<0.05)$. significantly $(p<0.05)$. The total chlorophyll in leaves after $55 \mathrm{~d}$ of EO treatment had decreased significantly in comparison with the controls $(p<0.05)$; after $103 \mathrm{~d}$ under the same conditions, the chlorophyll content was only slightly different from the controls (Fig. 2). Compared to the controls, the EC treatment caused slight changes in $\mathrm{Pn}$ and chlorophyll contents, but $\mathrm{Cs}, \mathrm{Ci}$ and $\mathrm{Tr}$ values in this treatment were significantly higher $(p<0.05)$ by day 55. In treatment EC, all photosynthetic parameters were significantly elevated $(p<$ 0.05 ) by day 103. Pn and chlorophyll contents were not significantly different between the EOEC treatment and the controls $(p>0.05)$, but $\mathrm{Ci}$ and $\mathrm{Tr}$ values in the EOEC treatment were significantly higher than those in controls $(p<0.05)$ on days 55 and 103. Gs values in the EOEC treatment were significantly higher than those in the controls $(p<0.05)$ after $55 \mathrm{~d}$ of exposure, but the treatment effect was slight by day
103. Other than $\mathrm{Ci}$, all of the photosynthetic parameters of $I$. decorus leaves subjected to EOEC treatment were significantly higher than those in the EO treatment ( $p$ $<0.05$ ), and significantly lower than those in the EC treatment $(p<0.05)$ (Fig. 2). Pn and $E$ values of $I$. decorus leaves after $55 \mathrm{~d}$ of exposure to all treatments were significantly higher than those after $103 \mathrm{~d}$ of exposure $(p<0.05)$, but this trend was reversed for $\mathrm{Ci}$. After $55 \mathrm{~d}$ of exposure, $\mathrm{Gs}$ values in the EOEC treatment, and chlorophyll contents in the control and treatment EOEC were also significantly higher than those on day $103(p<0.05)$. Overall, the responses of Gs and chlorophyll contents to $E O$ and $E C$ treatments were slight on days 55 and 103.

\section{Effects of elevated $\mathrm{CO}_{2}$ and $\mathrm{O}_{3}$ on} antioxidant enzyme activities

Compared with the controls, the APX activity of $I$. decorus leaves after $55 \mathrm{~d}$ of EO treatment was significantly elevated ( $p<$ $0.05)$, but the activities of SOD, POD and CAT were significantly reduced $(p<0.05)$ (Fig. 3). After $103 \mathrm{~d}$ of the same treatment, the activities of CAT, APX and POD were significantly elevated $(p<0.05)$, but SOD activity changed only slightly. After 55 and $103 \mathrm{~d}$ of exposure to the EC treatment, the activities of all enzymes had decreased significantly $(p<0.05)$. After $55 \mathrm{~d}$ of exposure to the EOEC treatment, the activities of $S O D, P O D$ and CAT were significantly reduced $(p<0.05)$, but APX activity was little affected. After $103 \mathrm{~d}$ of exposure to the same treatment, the activities of SOD and POD were significantly reduced $(p<0.05)$, but the activities of CAT and APX were little affected. The antioxidant enzyme activities of I. decorus leaves in the EOEC treatment were generally lower than those in the EO treatment, but higher than those in the EC treatment. On day 55, the activities of SOD and POD in all treatments were signifi- 
Fig. 3 - Effects of elevated ozone and/or elevated carbon dioxide on the activity of (A) superoxide dismutase (SOD), (B) peroxidase (POD), (C) catalase (CAT), and (D) ascorbate peroxidase (APX) in the leaves of Indocalamus decorus. Values are means \pm standard deviation of the three independent open-topped chambers (OTCs). Different upper case letters indicate significant differences between days of exposure $(p<0.05)$; different lowercase letters indicate significant differences among treatments $(p<0.05)$.
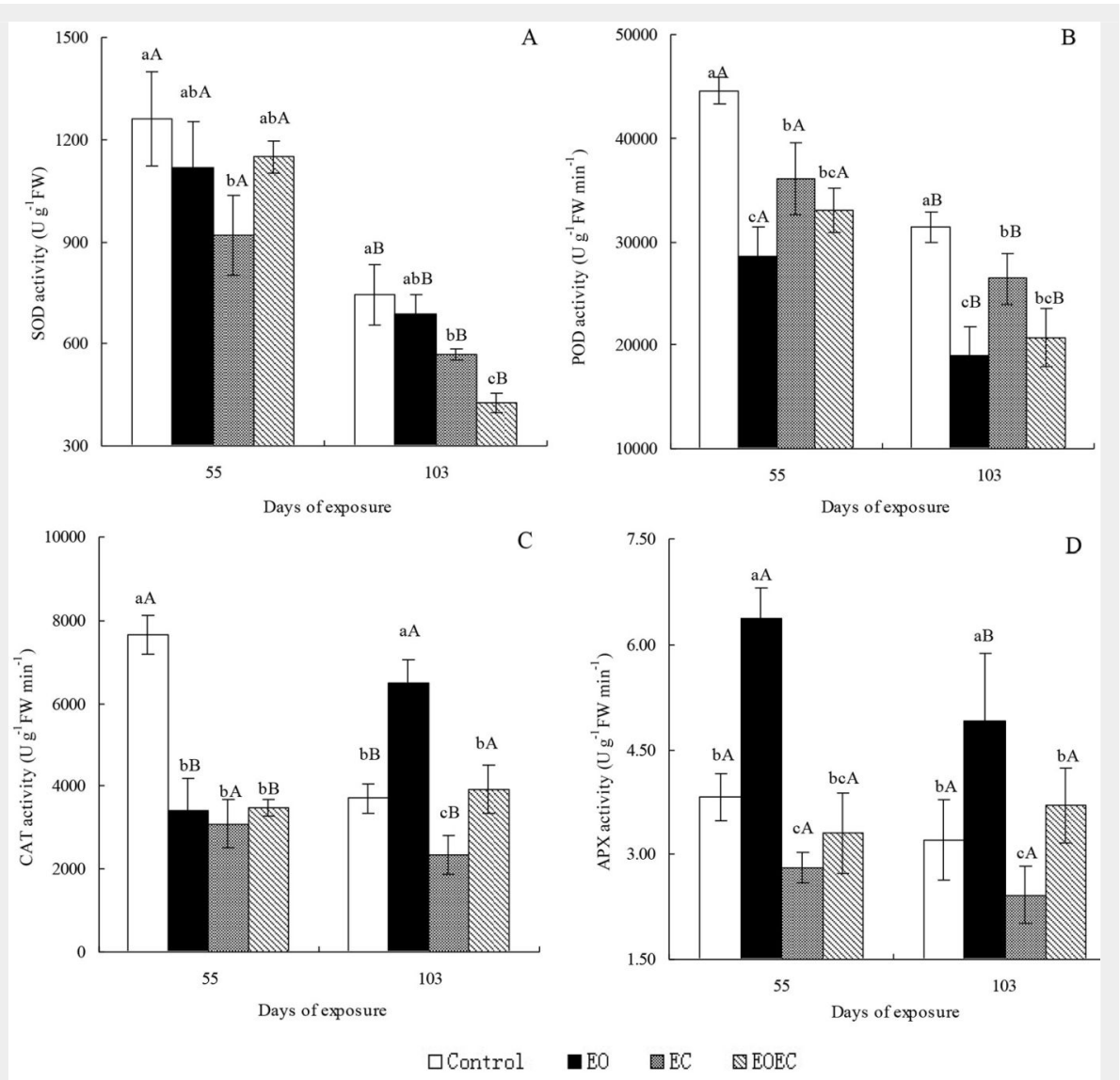

cantly higher than those on day 103 ( $p<$ 0.05 ). CAT activities in the control and EC treatments followed the trends in SOD and POD activities; however, CAT activities in the EO and EOEC treatments tracked a reverse trend. APX activity after $55 \mathrm{~d}$ of exposure to the EO treatment was significantly higher than the activity on day 103 , but this difference in APX activity between experimental days was not apparent in other treatments.

\section{Discussion}

\section{Elevated $\mathrm{O}_{3}$ tolerance}

Yan et al. (2010) reported severe oxidative damage and breakage of membrane structures in selected crops and deciduous trees subjected to $\mathrm{O}_{3}$ treatment. In contrast, we found that the contents of $\mathrm{O}_{2}$. and MDA, and the electrolyte leakage rate in the leaves of $I$. decorus were not significantly affected by elevated $\mathrm{O}_{3}$ treatments $\left(100\right.$ or $80 \mathrm{nmol} \mathrm{ml}^{-1}$ ). Thus, this bamboo species is strongly tolerant of elevated $\mathrm{O}_{3}$ levels. This adaptive trait has also been reported for subtropical evergreen tree species, such as Pinus elliottii and llex integra (Zhang et al. 2011).

However, the photosynthetic physiology parameters of $I$. decorus leaves were sensitive to elevated $\mathrm{O}_{3}$. Pn decreased significantly after $55 \mathrm{~d}$ of exposure, which is a common effect among plants. Gs reduction may be an important protective mechanism that limits the entry of $\mathrm{O}_{3}$ into the leaves through the stomatal apertures when the gas is at elevated concentrations, as demonstrated in previous investigations on Populus (Guidi et al. 2001), Ginkgo biloba (He et al. 2007), and Quercus mongolica (Yan et al. 2010). The reversed trends in Gs and $\mathrm{Ci}$ values in the leaves of $\mathrm{I}$. decorus under elevated $\mathrm{O}_{3}$ conditions indicate that the Pn decline was not due to a $\mathrm{Ci}$ decrease caused by changes in stomatal conductance (Gs); the decline of photosynthesis was mainly due to a decline in the activity of photosynthetic organs. Based on the reverse trends of $\mathrm{Gs}$ and $\mathrm{Ci}$ in the leaves, $P n$ reduction was most likely caused by non-stomatal factors, in accordance with the theory of Farquhar \& Sharkey (1982). The chlorophyll content of $I$. decorus leaves decreased significantly in elevated $\mathrm{O}_{3}$ treatments, which also indicates that Pn reduction was caused mainly by the activity of the photosynthetic system (including light energy utilization) and not by stomatal limitation (Li et al. 2012). At $103 \mathrm{~d}$ of exposure, $\mathrm{Pn}$ also decreased significantly; chlorophyll content had changed slightly by that time, indicating that the Pn decrease was caused mainly by inhibition of the the carboxylation process by elevated $\mathrm{O}_{3}$ levels. Thus, the carbon fixation rate was reduced (Mediavilla et al. 2002, Yan et al. 2010).

At $55 \mathrm{~d}$ of elevated $\mathrm{O}_{3}$ exposure, the activities of SOD, POD and CAT of I. decorus leaves decreased significantly compared with control leaves. The $\mathrm{O}_{2}{ }^{-}$and MDA contents, and the electrolyte leakage rate also decreased to some extent. All of these indicators show that elevated $\mathrm{O}_{3}$ resulted in stomatal closure, thereby preventing the entry of this gas into the leaf mesophyll (Zhuang et al. 2012). Thereafter, the generation of $\mathrm{O}_{2} \cdot$ and MDA, and the substrate for enzyme synthesis decreased over time. We found that APX was strongly sensitive to elevated $\mathrm{O}_{3}$ concentrations. After $103 \mathrm{~d}$ of exposure to elevated $\mathrm{O}_{3}$ levels, the activities of CAT and APX were significantly elevated, but the contents of $\mathrm{O}_{2} \cdot$ and MDA, and the electrolyte leakage rate were little affected. Yan et al. (2010) demonstrated that elevated $\mathrm{O}_{3}$ levels enhance the activities of antioxidant enzymes, thereby maintaining a balance between the generation and elimination of reactive oxygen species (ROS) and the integrity of the cell membrane structures in the leaves. POD with IAA oxidase properties is an important $\mathrm{H}_{2} \mathrm{O}_{2}$ eliminator that also catalyzes oxidation products of the electron donor to generate ROS that promote plant aging (Asada 1992). We showed that the POD activity of I. decorus leaves decreased significantly when $\mathrm{O}_{3}$ concentrations were elevated, demonstrating that $\mathrm{POD}$ played a vital role in $\mathrm{H}_{2} \mathrm{O}_{2}$ elimination. The enhancement of antioxidant enzyme activities in leaves during the late treatment period increased $\mathrm{O}_{3}$ tolerance in I. decorus.

\section{Physiological and biochemical} responses to elevated $\mathrm{CO}_{2}$ levels

$\mathrm{CO}_{2}$ is the substrate of Rubisco. The concentration of this gas affects the activity and catalytic direction of Rubisco, and adjusts the electron transfer rate and the pro- 
portions of diverse metabolic pathways. Thus, elevated $\mathrm{CO}_{2}$ levels may impact the photosynthetic process, but may also adjust the states of reactive oxygen species (Lin \& Wang 2000). Elevated $\mathrm{CO}_{2}$ levels can inhibit the formation of reactive oxygen species (Karnosky et al. 2005) and reduce the degree of membrane lipid peroxidation (Gaucher et al. 2003) by increasing the $\mathrm{CO}_{2} / \mathrm{O}_{2}$ ratio. We showed that elevated $\mathrm{CO}_{2}$ levels reduced the generation of reactive oxygen species in the leaves of $I$. decorus, reduced the degree of membrane lipid peroxidation, maintained the integrity of the cell membrane, and enhanced acclimation capability through $103 \mathrm{~d}$ of treatment. The effects of $\mathrm{CO}_{2}$ elevation are probably expressed in the next shoot growth season. It is likely that increased $\mathrm{CO}_{2}$ benefits shoot sprouting, growth and development in young bamboo plants with a high carbohydrate demand.

Since $\mathrm{CO}_{2}$ is a substrate for plant photo synthesis, carboxylation and photosynthetic rates will be improved by enhancing $\mathrm{CO}_{2}$ competition for binding sites on the Rubis co molecule (which also catalyzes a reac tion between the ribulose-1.5-bisphosphate and molecular oxygen), and by inhibiting photorespiration (Ellsworth et al. 2004 Handa et al. 2005, Noormets et al. 2010) However, elevated $\mathrm{CO}_{2}$ may promote photosynthetic acclimation and a reduction in Pn (Zheng \& Peng 2001). We found that Pn increased significantly in $I$. decorus during the period of elevated $\mathrm{CO}_{2}$ treatment, sug gesting that photosynthetic acclimation did not occur during the treatment; thus, we identified a significant positive effect of elevated $\mathrm{CO}_{2}$. In most cases, elevated $\mathrm{CO}_{2}$ reduces $G s$ in leaves, reduces $\mathrm{Tr}$, and elevates $\mathrm{Ci}$ (Kimball et al. 2002, Booker \& Fiscus 2005). However, that was not the case in our study. After $103 \mathrm{~d}$ of $\mathrm{CO}_{2}$ exposure, Gs and $\mathrm{Tr}$ had increased significantly, and $\mathrm{C}$ had decreased (significantly). We propose that these responses represent an adaptive adjustment that prevented the occurrence of photosynthetic acclimation. How ever, the mechanism underlying this ad justment remains unclear. Chlorophyll content increased significantly after 103 days of $\mathrm{CO}_{2}$ exposure. We propose that the extended elevated $\mathrm{CO}_{2}$ treatment promoted photosynthesis in I. decorus, enhanced leaf transpiration, and accelerated plant growth rate.

The antioxidant enzyme activities of $I$. decorus leaves decreased significantly in the elevated $\mathrm{CO}_{2}$ treatment, confirming an earlier proposal that elevated $\mathrm{CO}_{2}$ levels shift antioxidant enzymes into a "slack" state (Schwanz \& Polle 1998). Elevated CO levels increase intercellular $\mathrm{CO}_{2}$ concentrations and raise the $\mathrm{CO}_{2} / \mathrm{O}_{2}$ ratio at Rubisco binding sites to promote increased carboxylation efficiency of the enzyme, thereby enhancing the photosynthetic phosphory lation in I. decorus leaves. Increased carbohydrate contents in leaves improves NADP utilization by the PSI electron acceptor and limits electron flow to molecular oxygen, thereby inhibiting the Mehler reaction and reducing the generation rate of toxic $\mathrm{O}_{2}$ and reactive oxygen species. Antioxidant enzyme activity decreases in response (Ruan et al. 2007).

\section{Physiological and biochemical} responses to combinations of elevated $\mathrm{O}_{3}$ and $\mathrm{CO}_{2}$

The combined effects of elevated $\mathrm{O}_{3}$ and $\mathrm{CO}_{2}$ on contents of $\mathrm{O}_{2} \cdot$ and MDA, and electrolyte leakage rate were similar to those of the elevated $\mathrm{O}_{3}$ treatment, and were slightly different from those in the controls. Thus, we detected no significant interaction between elevated $\mathrm{O}_{3}$ and elevated $\mathrm{CO}_{2}$ on leaf membrane lipid peroxidation.

At $55 \mathrm{~d}$ of the combined $\mathrm{O}_{3}$ and $\mathrm{CO}_{2}$ treatment, the $\mathrm{Gs}$ and $\mathrm{Ci}$ values of I. decorus leaves had increased significantly, but those of Pn and chlorophyll content decreased slightly. However, Gs values in the combined gas treatment were significantly higher than those in elevated $\mathrm{O}_{3}$ treatment, and lower than those in the elevated $\mathrm{CO}_{2}$ treatment. Thus, we detected an interaction between the elevated levels of $\mathrm{O}_{3}$ and $\mathrm{CO}_{2}$, and suggest that the elevated $\mathrm{CO}_{2}$ increased stomatal conductance, thereby increasing the volumes $\mathrm{O}_{3}$ and $\mathrm{CO}_{2}$ entering the tissues simultaneously. We propose that the measured reduction in the photosynthetic rate was related to the elevated inflow of $\mathrm{O}_{3}$ and the metabolic dominance of this gas, as reported in a previous study of soybean (Glycine max - Booker \& Fiscus 2005). After $103 \mathrm{~d}$ of combined gas treatment, the $\mathrm{Gs}$ and $\mathrm{Ci}$ levels in the bamboo leaves decreased; these reductions contributed to the balancing of intracellular $\mathrm{CO}_{2}$ and $\mathrm{O}_{3}$ levels, improving photosynthesis and reducing transpiration, thereby maintaining normal physiological activities in the plants. The process was associated with significant increases in chlorophyll content, which promoted a significant increase in $\mathrm{Pn}$ and a reduction of $\mathrm{Tr}$ in leaves, indicating that $\mathrm{CO}_{2}$ may have been dominant.

At $55 \mathrm{~d}$ of the combined gas treatment, the activities of SOD, POD and CAT decreased significantly; APX activity declined slightly. This combination of effects may have been related to the dominance of $\mathrm{O}_{3}$ on day 55. The low levels of reactive oxygen species in the leaves indicate that that the antioxidant enzymes had played a role in the elimination of reactive oxygen species. The sensitivities of SOD, POD and CAT exceeded that of APX. After $103 \mathrm{~d}$ of the combined gas treatment, the activities of SOD and POD were significantly reduced, but the activities of CAT and APX had not changed significantly. This combination of effects may be related to $\mathrm{CO}_{2}$ dominance, which promoted an increase in the $\mathrm{CO}_{2} / \mathrm{O}_{2}$ ratio, reductions in the generation of reactive oxygen species, and decreases in membrane peroxidation.

\section{Conclusions}

Elevated $\mathrm{O}_{3}$ levels inhibited photosynthesis to a measurable extent in I. decorus. Pn limitation was related to non-stomatal factors, and was not associated with membrane lipid peroxidation. Thus, I. decorus was strongly tolerant of elevated $\mathrm{O}_{3}$.

Elevated $\mathrm{CO}_{2}$ levels significantly promoted photosynthesis in I. decorus, increased the $\mathrm{CO}_{2} / \mathrm{O}_{2}$ ratio, and reduced the reactive oxygen species content and antioxidant enzyme activities in leaves. Therefore, elevated $\mathrm{CO}_{2}$ had significant positive effects on I. decorus growth.

The combination of elevated $\mathrm{CO}_{2}$ and $\mathrm{O}_{3}$ concentrations did not reduce photosynthesis or cause oxidative damage in I. decorus; we detected an interactive effect between the gases. In the early treatment period (after 55 days), $\mathrm{O}_{3}$ may have been dominant, with consequently negative effects on I. decorus growth, but later in the treatment period ( 103 days), $\mathrm{CO}_{2}$ may have been dominant, with consequently positive effects on I. decorus growth.

\section{Ackowledgements}

The project was supported by the Natural Science Foundation of Zhejiang Province (No. LY13C160001) and by fundamental research funds for Central Non-Profit Research Institutes (No. RISF2014006).

\section{References}

Asada K (1992). Ascorbate peroxidase: a hydrogen peroxide-scavenging enzyme in plant. Physiologia Plantarum 85: 235-241. - doi: 10.1111/j.13 99-3054.1992.tb04728.x

Bai YM, Wang CY, Wen M (2005). Responses of soybean to $\mathrm{O}_{3}, \mathrm{CO}_{2}$ and their combination. Chinese Journal of Applied Ecology 16 (2): 545-549. [in Chinese with English abstract] [online] URL: http://europepmc.org/abstract/med/15943374 Booker FL, Fiscus EL (2005). The role of ozone flux and antioxidants in the suppression of ozone injury by elevated $\mathrm{CO}_{2}$ in soybean. Journal of Experimental Botany 56 (418): 2139-2151. - doi: 10.1093/jxb/eri214

Chen JX, Wang XF (2006). Experiment instruction of plant physiology. South China University Technology Press, Guangzhou, China, pp. 54124. [in Chinese]

Darbah JNT, Kubiske ME, Nelson N, Oksanen E, Vapaavuori E, Karosky DF (2008). Effects of decadal exposure to interacting elevated $\mathrm{CO}_{2}$ and/or $\mathrm{O}_{3}$ on paper birch (Betula papyrifera) reproduction. Environmental Pollution 155: 446452. - doi: 10.1016/j.envpol.2008.01.033

Donnelly A, Craigon J, Black CR, Colls J, Landon G (2001). Does elevated $\mathrm{CO}_{2}$ ameliorate the impact of $\mathrm{O}_{3}$ on chlorophyll content and photosynthesis in potato (Solanum tuberosum)? Physiologia Plantarum 111: 501-511. - doi: 10.1034/j.13 99-3054.2001.1110410.x

Ellsworth DS, Reich PB, Naumburg ES, Koch GW, Kubiske ME, Smith SD (2004). Photosynthesis, carboxylation and leaf nitrogen responses of 16 species to elevated $\mathrm{CO}_{2}$ across four free-air $\mathrm{CO}_{2}$ enrichment experiments in forest, grassland and desert. Global Change Biology 10: 2121-2138. - doi: 10.1111/j.1365-2486.2004.00867.x 
Farquhar GD, Sharkey TD (1982). Stomatal conductance and photosynthesis. Annual Review of Plant Physiology 33: 317-345. - doi: 10.1146/an nurev.pp.33.060182.001533

Gaucher C, Costanzo N, Afif D, Mauffette Y, Chevrier N, Dizengremel P (2003). The impact of elevated ozone and carbon dioxide on young Acer saccharum seedlings. Physiologia Plantarum 117: 392-402. - doi: 10.1034/j.1399-30 54.2003.00046.x

Gaucher C, Costanzo N, Widden P, Renaud JP, Dizengremel P, Mauffette Y, Chevrier N (2006). Response to an ozone gradient of growth and enzymes implicated in to tolerance to oxidative stress in Acer saccharum (Marsh). Annals of Forest Science 63 (4): 387-397. - doi: 10.1051/fo rest:2006019

Guidi L, Cagno RD, Soldatini GF (2000). Screening of bean cultivars for their response to ozone as evaluated by visible symptoms and leaf chlorophyll fluorescence. Environmental Pollution 107: 349-355. - doi: 10.1016/S0269-7491 (99)00170-0

Guidi L, Nali C, Lorenzini G, Filippi F, Soldatini GF (2001). Effects of chronic ozone fumigation on the photosynthetic process of poplar clones showing different sensitivity. Environmental Pollution 113: 245-254. - doi: 10.1016/S0269-7491 (00)00194-9

Handa IT, Körner C, Hättenschwiler S (2005). A test of the tree-line carbon limitation hypothesis by in situ $\mathrm{O}_{2}$ enrichment and defoliation. Ecology 86 (5): 1288-1300. - doi: 10.1890/04-0711 He XY, Fu SL, Chen W, Zhao TH, Xu S, Tuba Z (2007). Changes in effects of ozone exposure on growth, photosynthesis, and respiration of Ginkgo biloba in Shenyang urban area. Photosynthetica 45 (4): 555-561. - doi: 10.1007/s11099007-0095-0

IPCC (2007). Climate change 2007: the physical science basis. Contribution of Working Group I to the $4^{\text {th }}$ Assessment Report of the IPCC (Solomon S, Qin D, Manning M, Chen Z, Marquis $M$, Averyt KB, Tignor M, Miller HL eds). Cambridge University Press, Cambridge, UK, pp. 18. Karnosky DF, Zak DR, Kubiske ME, Hendrey GR, Weinstein D, Nosal M, Percy KE (2005). Scaling ozone responses of forest trees to the ecosystem level in a changing climate. Plant, Cell and Environment 28: 965-981. - doi: 10.1111/j.13653040.2005.01362.x

Ke DS, Wang AG, Sun GC, Dong LF (2002). The effect of active oxygen on the activity of ACC synthase induced by exogenous IAA. Acta Botantic Sinica 44 (5): 551-556.

Kimball BA, Kobayashi K, Bindi M (2002). Responses of agricultural crops to free-air $\mathrm{CO}_{2}$ enrichment. Advances in Agronomy 77: 293368. - doi: 10.1016/S0065-2113(02)77017-X

Knorzer OC, Durner J, Boger P (1996). Alterations in the antioxidative system of suspensioncultured soybean cells (Glycine max) induced by oxidative stress. Physiologia Plantarum 97: 388396. - doi: 10.1034/j.1399-3054.1996.970225.x

Li Y, Chen SL, Xie SX, Li YC, Zhuang MH, Guo ZW, Yang QP (2012). Effects of atmospheric ozone stress on photosynthetic physio- response of three dwarf bamboos. Journal of Tropical and Subtropical Botany 20 (3): 263-269. [in Chinese with English abstract]

Lin JS, Wang GX (2000). Effects of doubled $\mathrm{CO}_{2}$ concentration on antioxidant enzymes and programmed cell death of wheat leaves under osmotic stress. Acta Phytophysiologica Sinica 26 (5): 453-457. [online] URL: http://agris.fao.org/ agris-search/search.do?recordID=CN200130012 9

Meyer U, Kollner B, Willenbrink J, Krause GHM (2000). Effects of different ozone exposure regimes on photosynthesis, assimilates and thousand grain weight in spring wheat. Agriculture, Ecosystems and Environment 78: 49-45. doi: 10.1016/S0167-8809(99)00111-5

Mediavilla S, Santiago H, Escudero A (2002). Stomatal and mesophyll limitations to photosynthesis in one evergreen and one deciduous Mediterranean oak species. Photosynthetica 40 (4): 553-559. - doi: 10.1023/A:1024399919107 Noormets A, Sôber A, Pell EJ, Dickson RE, Podila GK, Sôber J, Isebrands JG, Karnosky DF (2001). Stomatal and non-stomatal limitation to photosynthesis in two trembling aspen (Populus tremuloides Michx) clones exposed to elevated $\mathrm{CO}_{2}$ and/or $\mathrm{O}_{3}$. Plant, Cell and Environment 24: 327-336. - doi: 10.1046/j.1365-3040.2001.00678.x Noormets A, Kull O, Sôber A, Kubiske ME, Karnosky DF (2010). Elevated $\mathrm{CO}_{2}$ responses of photosynthesis depends on ozone concentration in aspen. Environmental Pollution 158: 992999. - doi: 10.1016/j.envpol.2009.10.009

Nowak RS, Ellsworth DS, Smith SD (2004). Functional responses of plant to elevated atmospheric $\mathrm{CO}_{2}$ - do photosynthetic and productivity data from FACE experiments support early predictions? New Phytologist 162: 253-280. doi: 10.1111/j.1469-8137.2004.01033.x

Pleijel H, Eriksen AB, Danielsson H, Bondesson N, Sellden $G$ (2006). Different ozone sensitivity in an old and modern Swedish wheat cultivargrain yield and quality, leaf chlorophyll and stomatal conductance. Environmental and Experimental Botany 56: 63-71. - doi: 10.1016/j.env expbot.2005.01.004

Paoletti E, Seufert G, Rocca DG, Thomsen H (2007). Photosynthetic responses to elevated $\mathrm{CO}_{2}$ and $\mathrm{O}_{3}$ in Quercus ilex leaves at a natural $\mathrm{CO}_{2}$ spring. Environmental Pollution 147: 516524. - doi: 10.1016/j.envpol.2006.08.039

Ruan YN, He XY, Chen W, Xu S, Xu WD (2007). Effects of elevated $\mathrm{CO}_{2}$ on lipid peroxidation and activities of antioxidant enzymes in Ginkgo biloba. Chinese Journal of Acta Ecological Sinica 27 (3): 1106-1112. [in Chinese with English abstract]
Schwanz P, Polle A (1998). Antioxidative systems, pigment and protein contents in leaves of adult Mediterranean oak species (Quercus pubescens and Quercus ilex) with lifetime exposure to elevated $\mathrm{CO}_{2}$. New phytologist 140: 411423. - doi: 10.1046/j.1469-8137.1998.00290.x

Tausz M, Grulke NE, Wieser G (2007). Defense and avoidance of ozone under global change. Environmental Pollution 147: 525-531. - doi: 10.1016/j.envpol.2006.08.042

Vurro E, Bruni R, Bianchi A, Di Toppi LS (2009). Elevated atmospheric $\mathrm{CO}_{2}$ decreases oxidative stress and increases essential oil yield in leaves of Thymus vulgaris grown in a mini-FACE system. Environmental and Experimental Botany 65: 99-106. - doi: 10.1016/j.envexpbot.2008.09. 001

Wang MY, Zhao TH, Zhang WW, Guo D, He XY, Fu SL (2007). Effects of elevated $\mathrm{CO}_{2}$ concentration on photosynthetic characteristics of two urban forest species in Shenyang city. Chinese Bulletin of Botany 24 (4): 470-476. [in Chinese with English abstract]

Wustman BA, Oksanen E, Kammosky DF, Noormets A, Isebrands JG, Pregitzer KS, Hendrey GR, Sober J, Podila GK (2001). Effects of elevated $\mathrm{CO}_{2}$ and $\mathrm{O}_{3}$ on aspen clones varying in $\mathrm{O}_{3}$ sensitivity: can $\mathrm{CO}_{2}$ ameliorate the harmful effects of $\mathrm{O}_{3}$ ? Environmental Pollution 115: 473481. - doi: 10.1016/S0269-7491(01)00236-6 Yan K, Chen W, He XY, Zhang GY, Xu S, Wang LL (2010). Responses of photosynthesis, lipid peroxidation and antioxidant system in leaves of Quercus mongolica to elevated $\mathrm{O}_{3}$. Environmental and Experimental Botany 69: 198-204. - doi: 10.1016/j.envexpbot.2010.03.008

Zhang XZ, Chen YF (1994). Experimental techniques of plant physiology. Liaoning Technology Press, Shenyang, China, pp. 164-165. [in Chinese]

Zhang WW, Niu JF, Feng ZZ, Wang XK, Tian Y, Yao FF (2011). Responses of Ilex integra Thunb. seeding to elevated air ozone concentration. Environmental Science 32 (8): 2414-2421. [in Chinese with English abstract] [online] URL: http://europepmc.org/abstract/med/22619972 Zheng FY, Peng SL (2001). Meta-analysis of the response of plant ecophysiological variables to doubled atmospheric $\mathrm{CO}_{2}$ concentrations. Chinese Bulletin of Botany 43 (11): 1101-1109. [In Chinese with English abstract] [online] URL: http://en.cnki.com.cn/Article_en/CJFDTOTALZWXB200111000.htm

Zhuang MH, Li YC, Guo ZW, Yang QP, Gu LJ, Chen SL (2012). Physiological response of Indocalamus decorus to simulated atmospheric ozone stress with multiply-increasing concentrations. Journal of Plant Resources and Environment 21 (2): 68-72, 88. [in Chinese with English abstract] 